\title{
Responses of Chemical Functional Groups in Coleus Blumei Roots under Lead Stress with Exogenous Selenium Treatment Using 2-dimensional Correlation FTIR Spectra
}

\author{
Mianhao $\mathrm{Hu}^{1 *}$, Juhong Yuan ${ }^{2}$ \\ ${ }^{1}$ Institute of Ecological Economics, Jiangxi University of Finance and Economics, Nanchang, China \\ ${ }^{2}$ Institute of Environment and Plant Science, Jiangxi University of Finance and Economics, Nanchang, China
}

Received: 11 November 2017

Accepted: 18 January 2018

\begin{abstract}
Changes of chemical compositions in Coleus blumei roots under lead $(\mathrm{Pb})$ stress with different concentrations of selenium $(\mathrm{Se})$ treatments $(0,0.1,0.5,1.0,2.5$, and $5.0 \mathrm{mM})$ were analyzed by Fourier transform infrared (FTIR) spectrometry and 2-dimensional FTIR correlation spectroscopy. This was to investigate the spectroscopy differences and microscopic dynamics of chemical functional groups in C. blumei roots under $\mathrm{Pb}$ stress with exogenous selenium treatment. The results show that the peak shapes remained basically unchanged in $C$. blumei roots exposed to $\mathrm{Pb}$ stress with different concentrations of Se treatments, and the wave number of the absorption peaks remained stationary. However, there was a significant difference in absorption peak strength, which is influenced by chemical composition. Semiquantitative data indicate that there were obvious differences between the characteristics of the organic functional groups. There were differences between the 2D-FTIR correlation spectra of C. blumei roots in the region of $929-1,800 \mathrm{~cm}^{-1}$ under $\mathrm{Pb}$ stress with different concentrations of Se treatments, which are probably related to differences in chemical composition and structure. The FTIR spectra confirm the presence of various functional groups from the responses to abiotic stresses in the plant, and 2D-FTIR correlation spectroscopy may be a convenient and effective method in the study of plant molecular interactions under environmental stress.
\end{abstract}

Keywords: lead stress, exogenous selenium, Coleus blumei, 2-dimensional correlation FTIR spectra

\section{Introduction}

Lead $(\mathrm{Pb})$, the most common heavy metal pollutant, has caused great concern as a result of its widespread

*e-mail: yankeu1@163.com occurrence, toxic nature, and long duration in biological systems [1]. It mainly originates from mining and smelting activities, $\mathrm{Pb}$-containing paints, gasoline and explosives, cosmetics, storage batteries, fertilizers, herbicides, pesticides, and other industrial products [2-3], and from $\mathrm{Pb}$-enriched municipal sewage sludge [4]. Though regulatory measures have been adopted 
in many countries to control $\mathrm{Pb}$ input in the environment, it remains one of the most serious global environmental and human hazards [2]. With rapid developments in industry globally, many potential $\mathrm{Pb}$ sources are indispensable for modern human life, so soil pollution with $\mathrm{Pb}$ is not likely to be reduced in the near future [2]. These lead-cycles caused by anthropogenic sources are much more extended than the natural lead-cycle, and so it can accumulate in individual organisms, with subsequent accumulation along the entire food chain, which is a potential threat to human health [5]. Due to extensive use, their increased levels in the environment may lead to serious concerns for the environment and the global population.

In recent years, bioremediation has provided an alternative tool to destroy or render $\mathrm{Pb}$ contaminants non-toxic through biological activity. This method is cost effective, but $\mathrm{Pb}$ also causes plant injury [6]. Thus, plant response to $\mathrm{Pb}$ contamination is still a key problem, and a concerted effort is being made to find factors that influence the decrease of $\mathrm{Pb}$ absorption or toxicity in plants. Selenium (Se) plays an important role in conferring tolerance to $\mathrm{Pb}$ stresses in plants. Low concentrations of Se can improve cell viability in $\mathrm{Pb}$-treated plants [7]. However, the beneficial effects of higher concentrations of Se could be related to the reduction of lipid peroxidation and cell membrane injury [7-8]. The antagonistic effects of Se on the Pb-stressed plants were found to heavily depend on the Se dose in the nutrient solution [8]. Therefore, Se may be a useful tool for minimizing the toxic effects of lead toxicity through its potent antioxidant activity [9]. Some studies have also shown that selenium mitigation of $\mathrm{Pb}$ accumulation in plants could decrease the $\mathrm{Pb}$ bioavailability in soil [10-11]. The beneficial effects of $\mathrm{Se}$ on plants exposed to $\mathrm{Pb}$, and the possible mechanisms of the Se-enhanced resistance of plants to $\mathrm{Pb}$ toxicity, have been reported over a narrow range of concentrations. However, these mechanisms for Se-mediated detoxification of $\mathrm{Pb}$ have only involved the antioxidative stress response, so the mechanisms by which Se counteracts stress have not been fully clarified, and further research is necessary.

Two-dimensional correlation Fourier transform infrared FTIR spectroscopy (2D-FTIR) is a relatively new spectroscopic technique. It has been widely used to analyze spectral signals that change as functions of time, as well as other physical variables such as temperature, pressure, and concentration [12]. It can be useful for extracting more information from the chemical spectra, and elucidating the dynamic changes of functional groups, and the intramolecular and intermolecular interaction exposure to different conditions [13]. Biomolecules (proteins, polysaccharides, and in some instances lignin and other phenolic compounds) confer the ability to bind heavy metals non-covalently and/or covalently via functional groups [14], resulting in an enhanced stabilization ability of heavy metals in the plant [15]. However, the binding ability depends on the amount of various functional groups in the plant, such as hydroxyl, carboxyl, and carbonyl groups [16], and is important for a long-term heavy metal stabilization strategy in the plant or contaminated soils [15]. Previous research has shown that appropriate Se supplementation may ameliorate $\mathrm{Pb}$ induced oxidative stress by decreasing lipid peroxidation and altering the antioxidant defense system [17]. However, the possible interaction mechanism of organic molecules constitutes a variety of functional groups, and the chemical composition of the coleus plant is not yet fully understood. Therefore, the major objective of the present study was to investigate the functional group changes in Coleus blumei roots under $\mathrm{Pb}$ stress with the exogenous application of Se using FTIR and 2D-FTIR. We hoped to understand the molecular structure differences of Se-mediated detoxification, and to provide a new perspective on the unique role of $\mathrm{Se}$ in counteracting the negative effects of various environmental stresses in plants.

\section{Materials and Methods}

\section{Plant Pre-Treatment and Experimental Design}

Coleus (Coleus blumei benth.) used in this study was from the clone continually propagated in the Botanical Garden, Nanchang, Jiangxi, China. The plants were washed with tap water to allow them to adapt to a water environment. After one month, these plants were transferred to $2.5 \mathrm{~L}$ pots (16 plants per pot) containing 1/4 strength Hoagland nutrient solution (HNS) [18]. Plants were acclimatized in the hydroponic system for 2 weeks. Experiments were carried out using the simplest hydroponic system, i.e., a water culture system with slight modifications (modified Hoagland nutrient solution, MHNS) [19]. The platform that contained the plants was made of Styrofoam and floated directly on the nutrient solution. Air was bubbled through the nutrient solution using an air pump connected to an air stone to supply oxygen to the roots of the plants. The experiment was set up as a completely randomized design with 7 treatments each and 4 replications. Based on preliminary experiments, the acclimated plants were transferred to the full-strength MHNS, which had $1.0 \mathrm{mM}$ lead $(\mathrm{Pb})$ in the form of $\mathrm{Pb}\left(\mathrm{NO}_{3}\right)_{2}$ (Sigma-Aldrich, St. Louis, MO, USA), and then different concentrations of sodium selenite $\left(\mathrm{Na}_{2} \mathrm{SeO}_{3}\right.$; Sigma $)$ $(0,0.1,0.5,1.0,2.5$, and $5.0 \mathrm{mM})$ were added. These treatments were denoted as Pb1.0Se0, Pb1.0Se0.1, Pb1.0Se0.5, Pb1.0Se1.0, Pb1.0Se2.5, and Pb1.0Se5.0, respectively. The coleus plants were kept in full-strength MHNS without $\mathrm{Pb}$ and $\mathrm{Se}$ as the control treatment (denoted $\mathrm{Pb} 0 \mathrm{Se} 0$ ). The solution was renewed every 7 days and was aerated continuously during the acclimatization period, and $\mathrm{pH}$ was maintained at 6.0-6.5. After the addition of $\mathrm{Pb}$ and the different concentrations of Se to the nutrient medium, the loss of water via transpiration was replenished by frequent additions of deionized water to 
maintain a constant volume. Plants were kept in a growth chamber with an $8 \mathrm{~h}$ light period at a light intensity of $450 \mu \mathrm{mol} / \mathrm{m}^{2} / \mathrm{s}, 25^{\circ} \mathrm{C} / 20^{\circ} \mathrm{C}$ (day $/$ night) temperature and $60-70 \%$ relative humidity. Plants were harvested 21 days after each treatment. Upon harvest, each plant was separated into roots, stems, and leaves, and killed out for $30 \mathrm{~min}$ at $105^{\circ} \mathrm{C}$ in an air blowing thermostatic oven, then dried to constant weight at $65^{\circ} \mathrm{C}$ for FTIR.

\section{Measure Method}

For FTIR analysis, the roots of coleus plants were oven-dried for $12 \mathrm{~h}$ at $65^{\circ} \mathrm{C}$ and ground to a fine powder with an agate mortar, followed by sieving through a $150 \mu \mathrm{m}$ mesh. Roots $(1.0 \mathrm{mg})$ were then mixed with $100 \mathrm{mg} \mathrm{KBr}$ and pressed into pellets. Each pellet was immediately placed into a sample holder and FTIR spectra (FTIR Nicolet 5700, Thermo Nicolet Corporation, Wisconsin, USA) were recorded with a resolution of $4 \mathrm{~cm}^{-1}$ and 64 scans in the range of $4,000-400 \mathrm{~cm}^{-1}$. Each root made 9 ingot pieces that collected spectra, and the average was taken as the roots spectra.

\section{Statistical Analysis}

OMNIC E.S.P.5.1 intelligent software and ATR correction were used for determining the background value before each treatment sample was measured. The spectra of FTIR was taken under Pb stress with different concentrations of Se treatments, and then the characteristic peak was screened according to the peak absorbance values. Treatments were analyzed using SigmaPlot12.0 (SYSTAT Software Inc., California, USA), 2D Shige software created by Shigeaki Morita (Kwansei-Gakuin University, Japan), and OriginPro Version 8.5 (OriginLab Corporation, Northampton, USA) for $1 \mathrm{D}$ and $2 \mathrm{D}$ correlation analysis of FTIR spectra.

\section{Results and Discussion}

\section{D-FTIR Spectra Changes Analysis}

FTIR is useful for analyzing organic chemical composition as it can identify different functional groups that produce bond absorptions at different locations and intensities on the FTIR spectrum. Recognizing where the absorptions generated by the main functional groups occur can identify the properties, the formation, and the changes of chemical composition containing functional groups under different treatment conditions. The roots were characterized by FTIR spectroscopy to investigate the chemical differences between coleus roots under $\mathrm{Pb}$-induced stress and in the presence of different concentrations of Se. Table 1 shows the important spectral bands and the stretching vibration of their corresponding functional group assignments according to the literature. The Bands at $628-915 \mathrm{~cm}^{-1}$ were assigned to be aromatic $\mathrm{C}-\mathrm{H}$ out-of-plane bending. The bands at $1,000-1,033 \mathrm{~cm}^{-1}$ were attributed to $\mathrm{C}-\mathrm{O}$ stretching of polysaccharides. Absorption bands were noted at $1,270 \mathrm{~cm}^{-1}(\mathrm{C}-\mathrm{O}$ stretching of polysaccharides), $1,300-1,333 \mathrm{~cm}^{-1}\left(\mathrm{CH}_{2}\right.$ bending of structural carbohydrates), $1,384 \mathrm{~cm}^{-1} \quad \mathrm{CH}_{3}$ bending of lipids/proteins), $1,416 \quad \mathrm{~cm}^{-1} \quad\left(\mathrm{CH}_{2}\right.$ stretching of polysaccharide), 1,645 $\mathrm{cm}^{-1}$ (aromatic $\mathrm{C}=\mathrm{C}$ stretching), 2,130-2,353 $\mathrm{cm}^{-1}\left(\mathrm{C}=\mathrm{O}\right.$ stretching of $\left.\mathrm{CO}_{2}\right)$, 2,850-2,922 $\mathrm{cm}^{-1}$ (asymmetrical $\mathrm{CH}_{2}$ and symmetrical $\mathrm{CH}_{2}$ stretching of lipid/carbohydrate), and $3,410-3,900 \mathrm{~cm}^{-1}(\mathrm{O}-\mathrm{H}$ stretching of water and $\mathrm{N}-\mathrm{H}$ stretching of protein amide A).

The FTIR spectra of Coleus blumei roots exposed to $\mathrm{Pb}$ stress with different concentrations of Se treatments are presented in Fig. 1. The peak shape remained basically unchanged among the roots under $\mathrm{Pb}$-induced stress and different concentrations of Se. However, the peak strength did change and there was noticeable displacement of some peaks, as well as emergence/disappearance of some peaks (Fig. 1 and Table 2). This indicates that there were

Table 1. Functional groups assignment of FTIR bands.

\begin{tabular}{|c|c|}
\hline Wave number $\left(\mathrm{cm}^{-1}\right)$ & Vibrating type of functional groups \\
\hline $3,410-3,900$ & O-H stretching of Water [33-35]; $\mathrm{N}-\mathrm{H}$ stretching of protein amide $\mathrm{A}$ [32] \\
\hline $2,850-2,922$ & Asymmetrical $\mathrm{CH}_{2}$ and Symmetrical $\mathrm{CH}_{2}$ stretching of lipid/carbohydrate [32] \\
\hline $2,130-2,353$ & Aromatic $\mathrm{C}=\mathrm{C}$ stretching [29] \\
\hline 1,645 & $\mathrm{CH}_{2}$ stretching of polysaccharide [28] \\
\hline 1,416 & $\mathrm{CH}_{3}$ bending of lipids/proteins [24] \\
\hline 1,384 & $\mathrm{CH}_{2}$ bending of structural carbohydrates [26-27] \\
\hline $1,300-1,333$ & $\mathrm{C}-\mathrm{O}$ stretching of polysaccharides [25] \\
\hline 1,270 & $\mathrm{C}-\mathrm{O}$ stretching of polysaccharides [24] \\
\hline $1,000-1,033$ & Aromatic C-H out-of-plane bending [20-23] \\
\hline $628-915$ & \\
\hline
\end{tabular}




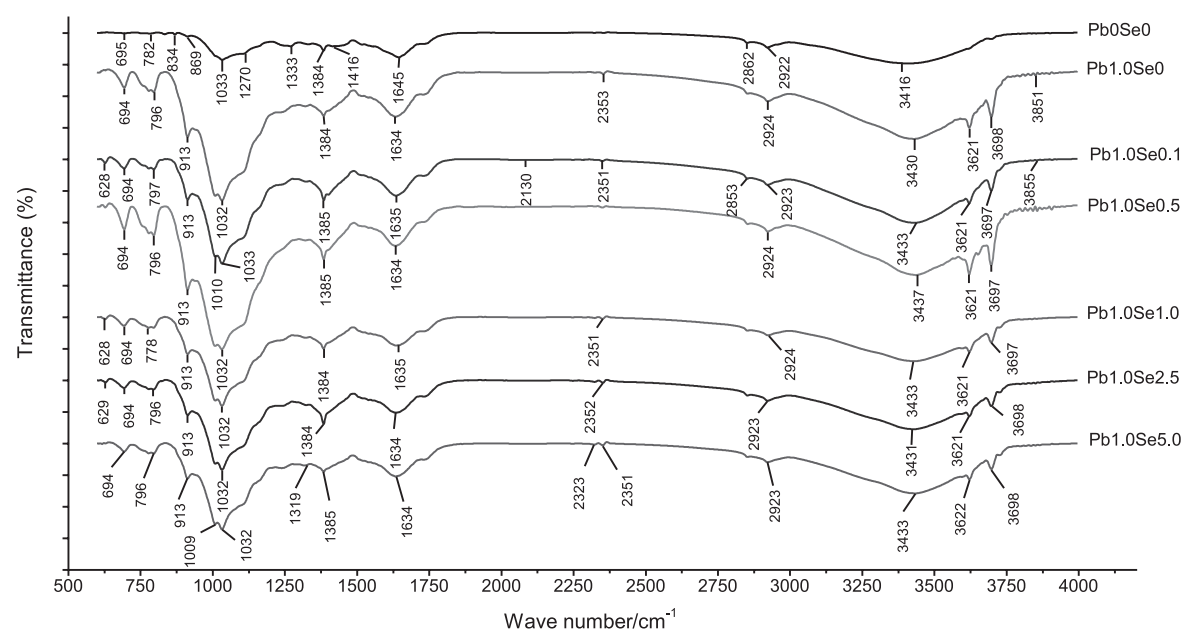

Fig. 1. FTIR spectra of Coleus blumei roots under $\mathrm{Pb}$ stress with different concentration of Se treatments $-\mathrm{Pb} 0 \mathrm{Se} 0: \mathrm{Pb} 0 \mathrm{mmol} / \mathrm{L}+\mathrm{Se}$ 0 mmol/L; Pb1.0Se0: Pb 1.0 mmol/L + Se 0 mmol/L; Pb1.0Se0.1: Pb 1.0 mmol/L + Se 0.1 mmol/L; Pb1.0Se0.5: Pb 1.0 mmol/L + Se 0.5 mmol/L; Pb1.0Se1.0: Pb 1.0 mmol/L + Se 1.0 mmol/L; Pb1.0Se2.5: Pb 1.0 mmol/L + Se 2.5 mmol/L; Pb1.0Se5.0: $\mathrm{Pb} 1.0 \mathrm{mmol} / \mathrm{L}+$ Se $5.0 \mathrm{mmol} / \mathrm{L}$; the same below.

no changes in the chemical composition of the roots, but that their contents were influenced by treatment with $\mathrm{Pb}$ and $\mathrm{Se}$. This finding is consistent with results from recent reports on grape pomace [36] and meager [37]. The absorption peaks displacement of certain functional groups involved in heavy metal adsorption changes to different degrees, e.g., the absorption peak of $\mathrm{OH}$ group $\left(3,416-3,900 \mathrm{~cm}^{-1}\right)$, and carbonyl group $\left(1,000-1,100 \mathrm{~cm}^{-1}\right.$, and $\left.1,270 \mathrm{~cm}^{-1}\right)$, which may act as $\mathrm{Pb}$ ligands and participate in the processes of $\mathrm{Pb}$ sequestration in coleus roots with exogenous Se treatments [38]. In addition, a new peak appeared at 2,130-2,353 $\mathrm{cm}^{-1}$ $\left(\mathrm{C}=\mathrm{O}\right.$ stretching of $\left.\mathrm{CO}_{2}\right)$ under $\mathrm{Pb}$ stress with different concentration of Se treatments, except for Pb1.0Se0.5, which demonstrates the existence of transition-metal complexes affecting intercellular $\mathrm{CO}_{2}[39]$.

Semi-quantitative data are used to compare spectral data from samples in order to obtain information on how different functional groups respond differently to environmental changes [40-41]. The following semi-quantitative measurements of FTIR spectra were analyzed by integrating the total peak area from: (1) 3,410-3,900 $\mathrm{cm}^{-1}(\mathrm{OH}$, aliphatic $\mathrm{O}-\mathrm{H}$ stretching); (2) $1,645 \mathrm{~cm}^{-1}(\mathrm{Cl}$, aromatic carbon groups $\mathrm{C}=\mathrm{C})$; (3) 1,420-1,300 $\mathrm{cm}^{-1}$ (CH, $\mathrm{CH}_{2}$ and $\mathrm{CH}_{3}$ compounds); (4) 1,000-1,270 $\mathrm{cm}^{-1}$ (Ox1, contribution of $\mathrm{C}-\mathrm{O}$ groups); and (6) $915-628 \mathrm{~cm}^{-1}$ (Ar, aromatic $\mathrm{C}-\mathrm{H}$ out-of-plane bending).

The $\mathrm{CH}_{2} / \mathrm{CH}_{3}$ ratio is the sum of the $\mathrm{CH}_{2}$ peak areas $\left(1,416\right.$ and $\left.2,850-2,922 \mathrm{~cm}^{-1}\right)$ divided by the sum of the $\mathrm{CH}_{3}$ peak areas $\left(1,384 \mathrm{~cm}^{-1}\right)$, which relates to aliphatic chain length and degree of branching of aliphatic side groups. A higher value implies comparatively longer and straighter chains; a lower value, shorter and more branched chains.

The $\mathrm{OH} / \mathrm{Ox} 1$ ratio is the ratio of the integrated area of the O-H stretching region $\left(3,410-3,900 \mathrm{~cm}^{-1}\right)$ divided by the integrated area of the oxygenated group region $\left(1,000-1,270 \mathrm{~cm}^{-1}\right)$. This is the relative contribution of $\mathrm{O}-\mathrm{H}$ stretching to the combined contribution of oxygencontaining groups, and can be inferred oxygen-containing groups decreasing from higher values.

The $\mathrm{Ox} 1 / \mathrm{C} 1$ ratio is the ratio of the integrated area of the (C-O) stretching region $\left(1,000-1,270 \mathrm{~cm}^{-1}\right.$ and the integrated area of the aromatic carbon $(\mathrm{C}=\mathrm{C})$ groups $\left(1,645 \mathrm{~cm}^{-1}\right)$. This is the relative contribution of $\mathrm{C}-\mathrm{O}$ to aromatic carbon groups, and higher values indicate increasing ratios of $\mathrm{C}-\mathrm{O}$ groups to aromatic carbon groups.

$\mathrm{Ar} / \mathrm{CHx}$ is the ratio of the integrated area of the aromatic C-H out-of-plane bending (915-628 $\mathrm{cm}^{-1}$ ) and the integrated area of the $\mathrm{CH}_{2}$ and $\mathrm{CH}_{3}$ stretching region $\left(2,850-2,922\right.$ and $\left.1,420-1,300 \mathrm{~cm}^{-1}\right)$. This is the contribution of aromatic $\mathrm{C}-\mathrm{H}$ out-of-plane bending modes to aliphatic $\mathrm{C}-\mathrm{H}$ stretching bands, and higher values indicate higher aromaticity in the organic matter.

The A factor is defined by the integrated area of the aliphatic stretching region $\left(2,850-2,922 \mathrm{~cm}^{-1}\right)$ divided by the sum of the integrated areas of the aliphatic stretching region $\left(2,850-2,922 \mathrm{~cm}^{-1}\right)$ and aromatic carbon structures $\left(1,645 \mathrm{~cm}^{-1}\right)$, representing changes in the relative intensities of the aliphatic groups.

The $\mathrm{C}$ factor is defined by the integrated area of the oxygenated group region $\left(1,000-1,270 \mathrm{~cm}^{-1}\right)$ divided by the sum of the integrated areas of the oxygenated group region (1,000-1,270 $\left.\mathrm{cm}^{-1}\right)$ and aromatic carbon structures $\left(1,645 \mathrm{~cm}^{-1}\right)$, representing changes in the $\mathrm{C}-\mathrm{O}$ groups.

All these ratios could also be used for comparative purposes, providing valuable information on the changes of chemical functional groups in C. blumei roots under $\mathrm{Pb}$ stress with different concentrations of Se treatments in an attempt to identify the differences in functional groups according to the proposal of Ganz and Kalkreuth [42].

Changes in the FTIR bands were used to obtain semi-quantitative data for $\mathrm{Pb}$ stress with different 


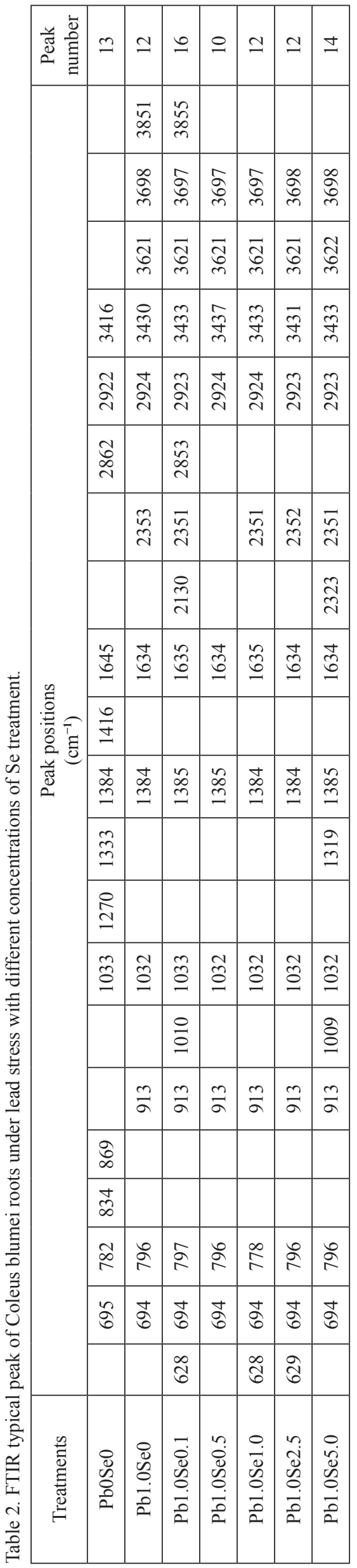

concentrations of $\mathrm{Se}$ treatments (Table 3). The $\mathrm{CH}_{2} / \mathrm{CH}_{3}$ ratio can be used as a discriminatory function for chemical composition [43]. The $\mathrm{CH}_{2} / \mathrm{CH}_{3}$ ratio in C. blumei roots for $\mathrm{Pb} 1.0 \mathrm{Se} 0$ showed the lowest value (0.66) in this study (Table 3). This indicates that $C$. blumei roots under $\mathrm{Pb}$ stress without $\mathrm{Se}$ had longer and straighter aliphatic chains compared with $\mathrm{Pb} 0 \mathrm{Se} 0$. However, the $\mathrm{CH}_{2} / \mathrm{CH}_{3}$ ratio of $C$. blumei roots under $\mathrm{Pb}$ stress with different concentrations of Se treatments showed lower values, except for the Pb1.0Se0.1 treatment. This indicates that the length and straightness of the aliphatic chains in the $C$. blumei roots were increased under $\mathrm{Pb}$ stress with Pb1.0Se0.5, Pb1.0Se1.0, Pb1.0Se2.5, and $\mathrm{Pb} 1.0 \mathrm{Se} 5.0$ - especially the $\mathrm{Pb} 1.0 \mathrm{Se} 0.5$ treatment. The Pb1.0Se0.1 treatment had a higher value (4.16), indicating that the $C$. blumei roots had shorter and more branched aliphatic chains under Pb stress with $0.1 \mathrm{mM}$ Se treatment.

For the OH/Ox1 ratio, the values for the $\mathrm{Pb} 1.0 \mathrm{Se} 0$ treatment decreased significantly compared with the $\mathrm{Pb} 0 \mathrm{Se} 0$ treatment, which indicates a larger contribution of oxygen-containing groups. However, the $\mathrm{OH} / \mathrm{Ox} 1$ ratio under $\mathrm{Pb}$ stress with different concentrations of Se treatments shows lower and similar values except for the Pb1.0Se2.5 treatment. The lowest value was for the $\mathrm{Pb} 1.0 \mathrm{Se} 0.5$ treatment, which indicates the largest contribution of oxygen-containing groups. In addition, the highest value was for the Pb1.0Se2.5 treatment, which indicates an increase in $\mathrm{OH}$ contribution.

For the $\mathrm{Ox} 1 / \mathrm{Cl}$ ratio, $\mathrm{Pb} 1.0 \mathrm{Se} 0$ treatment showed higher values compared with the $\mathrm{Pb} 0 \mathrm{Se} 0$ treatment, which indicates increasing ratios of $\mathrm{C}-\mathrm{O}$ groups to aromatic carbon groups. However, the $\mathrm{OH} / \mathrm{Ox} 1$ ratio under $\mathrm{Pb}$ stress with different concentrations of Se treatments decreased, except for the $\mathrm{Pb} 1.0 \mathrm{Se} 0.1$ and $\mathrm{Pb} 1.0 \mathrm{Se} 0.5$ treatments, which indicates a higher oxidation of organic matter in the Pb1.0Se1.0, Pb1.0Se2.5, and Pb1.0Se5.0 treatments. Meanwhile, there were higher values for the Pb1.0Se0.1 and $\mathrm{Pb} 1.0 \mathrm{Se} 0.5$ treatments compared with other treatment concentrations of $\mathrm{Se}$, which indicates increasing ratios of $\mathrm{C}-\mathrm{O}$ groups to aromatic carbon groups.

With respect to the aromatic $\mathrm{Ar} / \mathrm{CHx}$ ratio, the $\mathrm{Pb} 1.0 \mathrm{Se} 0$ treatment shows higher values compared to the $\mathrm{Pb} 0 \mathrm{Se} 0$ treatment, which indicates a higher aromaticity in the organic matter under $\mathrm{Pb}$ stress. However, the $\mathrm{Ar} / \mathrm{CHx}$ ratio under $\mathrm{Pb}$ stress with different concentrations of $\mathrm{Se}$ treatments decreased, except for the Pb1.0Se 0.5 treatment, which showed that the aromaticity of the organic matter was decreasing, especially for the Pb1.0Se0.1 treatment. However, the Pb1.0Se0.5 treatment showed the highest value, which indicates higher aromaticity in the organic matter.

Finally, the compressions of $C$. blumei roots for the $\mathrm{Pb} 1.0 \mathrm{Se} 0$ treatment were characterized by low values for A factor and high values for $\mathrm{C}$ factor, compared with the $\mathrm{Pb} 0 \mathrm{Se} 0$, which indicates low contents of aliphatic, and high contents of oxygen-containing compounds (Table 3 ). The compressions of $C$. blumei roots for $\mathrm{Pb}$ stress with the $0.1 \mathrm{mM}$ Se treatment were characterized by high values 
Table 3. Comparison of semi-quantitative FTIR data of Coleus blumei roots under lead stress with different concentrations of Se treatments.

\begin{tabular}{|c|c|c|c|c|c|c|}
\hline \multirow{2}{*}{ Treatments } & \multicolumn{6}{|c|}{ Ratio } \\
\hline & $\mathrm{CH}_{2} / \mathrm{CH}_{3}$ & $\mathrm{OH} / \mathrm{Ox} 1$ & $\mathrm{Ox} 1 / \mathrm{C} 1$ & $\mathrm{Ar} / \mathrm{CHx}$ & A factor & $\mathrm{C}$ factor \\
\hline $\mathrm{Pb} 0 \mathrm{Se} 0$ & 5.04 & 4.08 & 1.06 & 0.03 & 0.49 & 0.55 \\
\hline $\mathrm{Pb} 1.0 \mathrm{Se} 0$ & 0.66 & 1.52 & 3.90 & 0.48 & 0.35 & 0.79 \\
\hline $\mathrm{Pb} 1.0 \mathrm{Se} 0.1$ & 4.16 & 1.41 & 5.24 & 0.24 & 0.62 & 0.84 \\
\hline $\mathrm{Pb} 1.0 \mathrm{Se} 0.5$ & 0.49 & 0.98 & 4.86 & 0.68 & 0.27 & 0.83 \\
\hline $\mathrm{Pb} 1.0 \mathrm{Se} 1.0$ & 0.65 & 1.54 & 3.69 & 0.42 & 0.35 & 0.79 \\
\hline $\mathrm{Pb} 1.0 \mathrm{Se} 2.5$ & 0.54 & 1.79 & 3.27 & 0.31 & 0.35 & 0.77 \\
\hline $\mathrm{Pb} 1.0 \mathrm{Se} 5.0$ & 0.53 & 1.39 & 3.84 & 0.34 & 0.32 & 0.79 \\
\hline
\end{tabular}

for A factor and high values for $\mathrm{C}$ factor, compared with other concentration of Se treatments, which indicates high contents of aliphatic and high contents of oxygencontaining compounds, respectively.

\section{D-FTIR Correlation Spectra Analysis}

The synchronous and asynchronous 2D-FTIR correlation spectra of $C$. blumei roots under $\mathrm{Pb}$ stress with different concentrations of Se treatments in the region of $929-1,800 \mathrm{~cm}^{-1}$ are shown in Figs 2-8.

Fig. 2a shows the synchronous 2D correlation spectrum of $\mathrm{Pb} 0 \mathrm{Se} 0$ treatment based on autocorrelation calculations in the region of $1,000-1,645 \mathrm{~cm}^{-1}$. The peak at $1,000-1,033 \mathrm{~cm}^{-1}$ was attributed to the $\mathrm{C}-\mathrm{O}$ stretching of polysaccharides in $C$. blumei roots. The two peaks observed at $1,270 \mathrm{~cm}^{-1}$ and $1,384 \mathrm{~cm}^{-1}$ were attributed to the $\mathrm{C}$-O stretching of polysaccharides and $\mathrm{CH}_{3}$ bending of lipids/proteins in $C$. blumei roots, respectively. The peak at $1,645 \mathrm{~cm}^{-1}$ was assigned to the aromatic $\mathrm{C}=\mathrm{C}$ stretching vibration in $C$. blumei roots. Two positive cross-peaks observed at $(1,033,1,645) \mathrm{cm}^{-1}$ and $(1,270,1,384) \mathrm{cm}^{-1}$, and the 5 negative cross peak observed at $(1,033,1,270)$ $\mathrm{cm}^{-1},(1,033,1,384) \mathrm{cm}^{-1},(1,645,1,270) \mathrm{cm}^{-1},(1,645,1,384)$ $\mathrm{cm}^{-1}$, and $(1,384,1,270) \mathrm{cm}^{-1}$ result from the orientation of $\mathrm{C}-\mathrm{O}$, aromatic $\mathrm{C}=\mathrm{C}$, and $\mathrm{CH}_{3}$ vibrations generated at the same time. According to $2 \mathrm{D}$ correlation rules [44], the functional groups of $\mathrm{C}-\mathrm{O}$, aromatic $\mathrm{C}=\mathrm{C}$, and $\mathrm{CH}_{3}$ had a cooperative effect, but had the reverse direction of the intensity variations in these 2 correlated stretching vibration modes. In the asynchronous spectrum of the $\mathrm{Pb} 0 \mathrm{Se} 0$ treatment (Fig. 2b), according to the rule of Noda [44], the negative sign of the cross-peaks at $(1,033,1,270) \mathrm{cm}^{-1},(1,033,1,384) \mathrm{cm}^{-1}$, $(1,645,1,270) \mathrm{cm}^{-1},(1,645,1,384) \mathrm{cm}^{-1}$, and $(1,384$, 1,270) $\mathrm{cm}^{-1}$ indicates that the intensity change of the symmetric stretching vibration of functional groups occurs prior to that of the asymmetric one. On the basis of Noda's rule [44-45] and the method of Murayama et al. [46], the following sequence of the intensity variations was deduced: $\mathrm{C}-\mathrm{O}$ stretching of polysaccharides $\left(1,270 \mathrm{~cm}^{-1}\right) \approx \mathrm{CH}_{2}$ and $\mathrm{CH}_{3}$ in lipids $\left(1,384 \mathrm{~cm}^{-1}\right)>\mathrm{C}-\mathrm{O}$ stretching of polysaccharides $\left(1,033 \mathrm{~cm}^{-1}\right) \approx$ aromatic $\mathrm{C}=\mathrm{C}$ stretching $\left(1,654 \mathrm{~cm}^{-1}\right)$.

In the synchronous 2D correlation spectrum of the Pbl.0Se0 treatment (Fig. 3a), one auto-peak at
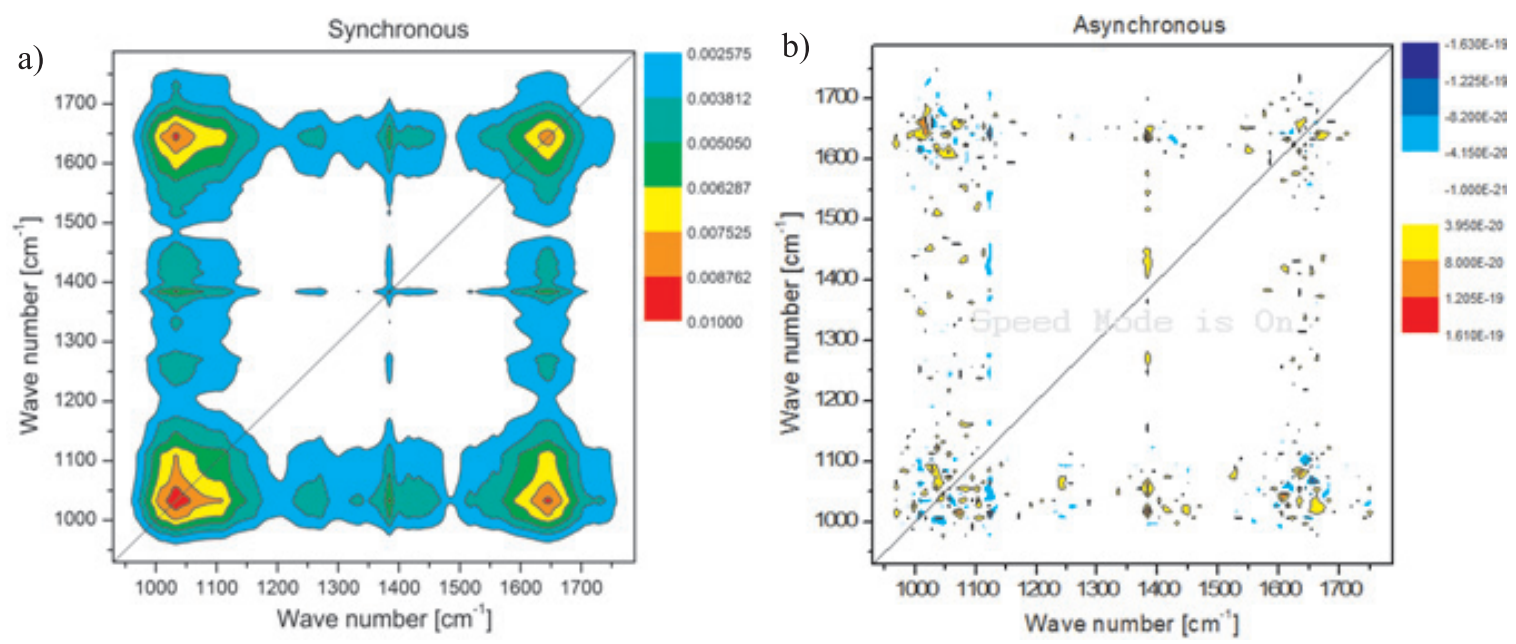

Fig. 2. Synchronous and asynchronous 2D-FTIR correlation spectra of Coleus blumei roots without lead and selenium. 

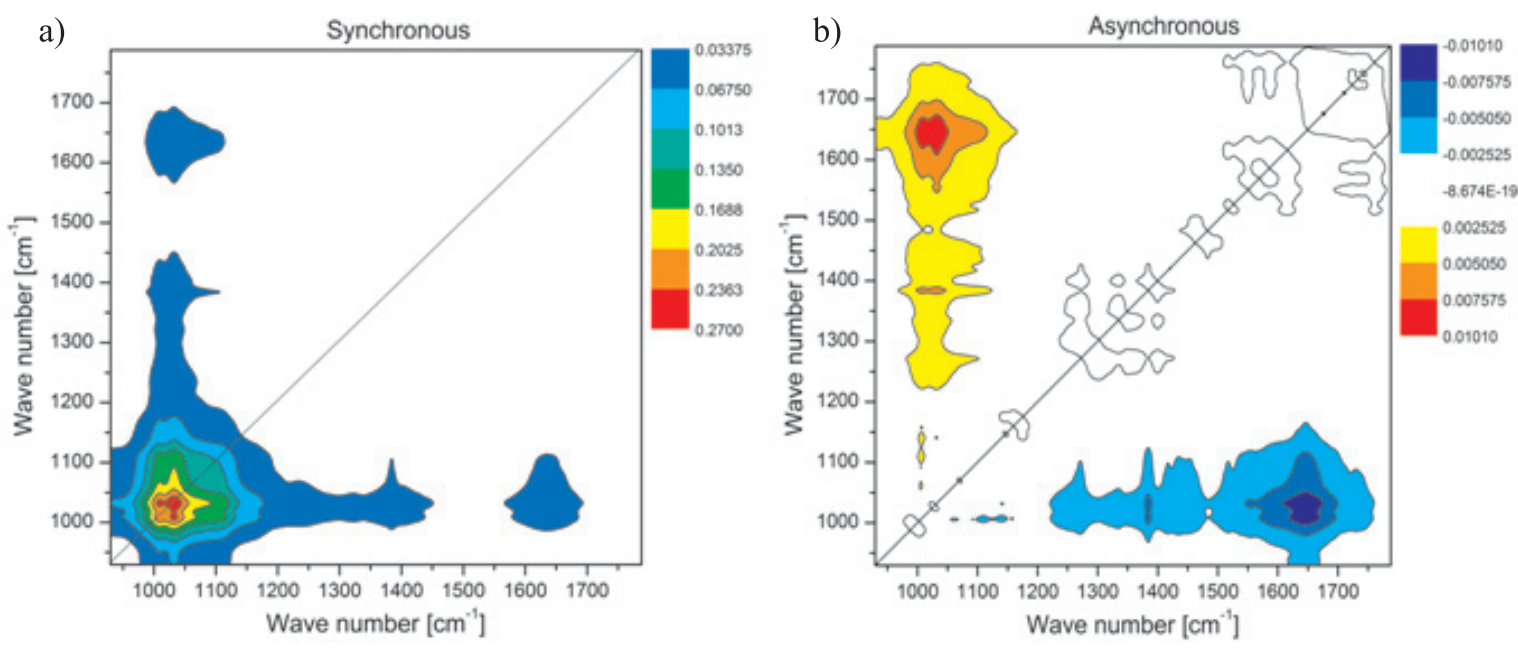

Fig. 3. Synchronous and asynchronous 2D-FTIR correlation spectra of Coleus blumei roots under $0 \mathrm{mM}$ and $1.0 \mathrm{mM}$ lead treatments.

$\Phi(1,000-1,150,1,000-1,150)>0$, one positive cross-peak at $\Phi(1,384,1,645)>0$, and 2 negative cross-peaks at $\Phi(1,000-1,150,1,384)<0$ and $\Phi(1,000-1,150,1,645)$ $<0$ were observed. This implies that the band from $1,000-1,150 \mathrm{~cm}^{-1}$ varies in the opposite direction to the bands at 1,384 and $1,645 \mathrm{~cm}^{-1}$. As has already been mentioned, these bands were assigned to $\mathrm{C}-\mathrm{O}$ stretching vibration in polysaccharides, $\mathrm{CH}_{3}$ bending of lipids/proteins, and aromatic $\mathrm{C}=\mathrm{C}$ stretching vibration, respectively. Thus it was observed that the C-O stretching vibrations $\left(1,000-1,150 \mathrm{~cm}^{-1}\right)$ vary in the opposite direction to the $\mathrm{CH}_{3}$ stretching $\left(1,384 \mathrm{~cm}^{-1}\right)$ and aromatic $\mathrm{C}=\mathrm{C}$ stretching $\left(1,645 \mathrm{~cm}^{-1}\right)$ under $\mathrm{Pb}$ treatment, compared with the $\mathrm{Pb} 0 \mathrm{Se} 0$ treatment. Three bands at $1,125 \mathrm{~cm}^{-1}, 1,384 \mathrm{~cm}^{-1}$, and $1,645 \mathrm{~cm}^{-1}$ were identified in the asynchronous $2 \mathrm{D}$ correlation spectrum of the $\mathrm{Pb} 1.0 \mathrm{Se} 0$ treatment (Fig. 3b). The sequence of the spectral intensity changes was obtained as follows: $1,125 \mathrm{~cm}^{-1}>1,384 \mathrm{~cm}^{-1}>1,645 \mathrm{~cm}^{-1}$. This sequence means that the moment of $\mathrm{C}-\mathrm{O}$ groups $\left(1,125 \mathrm{~cm}^{-1}\right)$ in polysaccharides changes first, followed by the $\mathrm{CH}_{3}$ stretching vibration in lipids/proteins, and the $\mathrm{C}=\mathrm{C}$ stretching of the aromatic skeleton under $\mathrm{Pb}$ stress.

In the synchronous $2 \mathrm{D}$ correlation spectrum of the Pb1.0Se0.1 treatment (Fig. 4a), one auto-peak at $\Phi(1,000$ $1,150,1,000-1,150)>0$, one positive cross-peak at $\Phi(1,384$, $1,645)>0$, and 3 negative cross-peaks at $\Phi(1,000-1,150$, $1,270)<0, \Phi(1,000-1,150,1,333)<0$ and $\Phi(1,000-1,150$, $1,645)<0$ were observed. This implies that the band from 1,000-1,150 $\mathrm{cm}^{-1}$ varies in the opposite direction to the bands at 1,384 and $1,645 \mathrm{~cm}^{-1}$. This indicates that the C-O stretching vibrations $\left(1,000-1,150 \mathrm{~cm}^{-1}\right)$ vary in the opposite direction to the $\mathrm{C}-\mathrm{O}$ stretching $\left(1,270 \mathrm{~cm}^{-1}\right)$, the $\mathrm{CH}_{3}$ stretching $\left(1,384 \mathrm{~cm}^{-1}\right)$, and the aromatic $\mathrm{C}=\mathrm{C}$ stretching $\left(1,645 \mathrm{~cm}^{-1}\right)$ under the $\mathrm{Pb} 1.0 \mathrm{Se} 0.1$ treatment, compared with the $\mathrm{Pb} 1.0 \mathrm{Se} 0$ treatment. Four bands at $1,033 \mathrm{~cm}^{-1}, 1,270 \mathrm{~cm}^{-1}, 1,333 \mathrm{~cm}^{-1}$, and $1,645 \mathrm{~cm}^{-1}$ were identified in the asynchronous 2D correlation spectrum of the Pb1.0Se0.1 treatment (Fig. 4b). The sequence of the spectral intensity changes was obtained as follows:
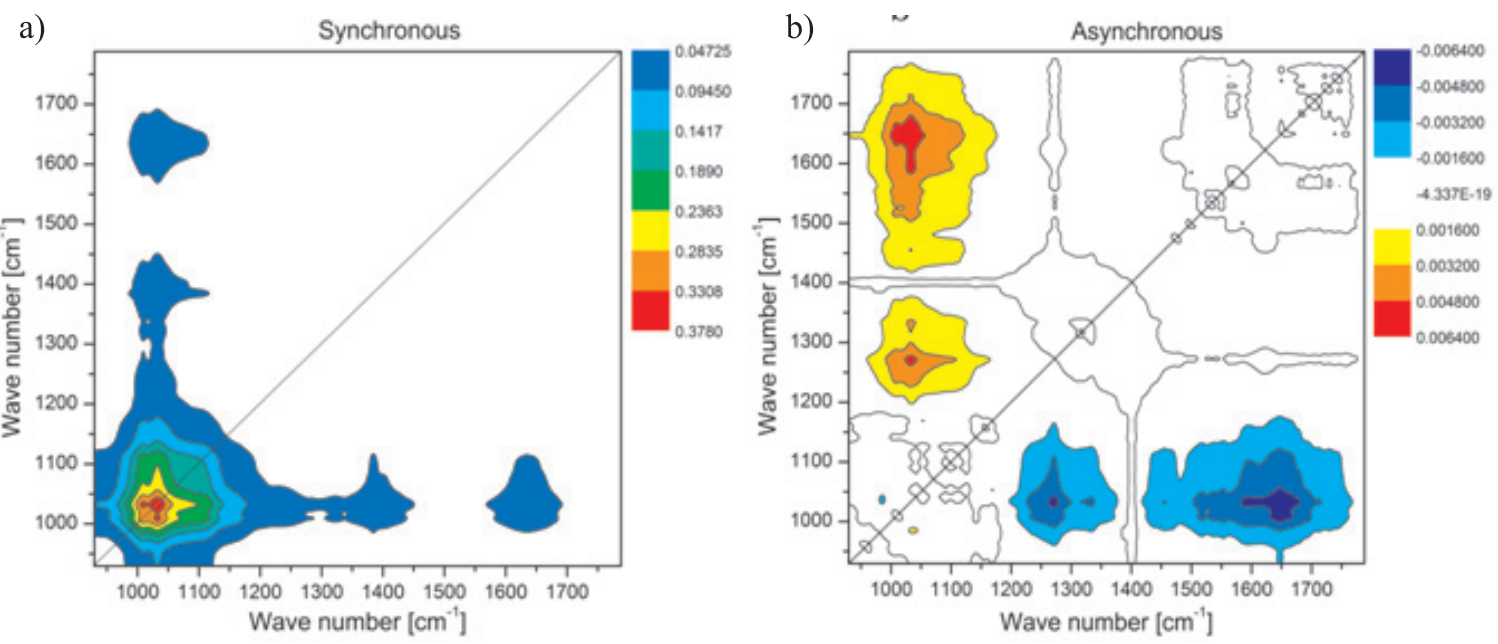

Fig. 4. Synchronous and asynchronous 2D-FTIR correlation spectra of Coleus blumei roots under $0 \mathrm{mM}$ and $1.0 \mathrm{mM}$ lead with $0.1 \mathrm{mM}$ Se treatment. 

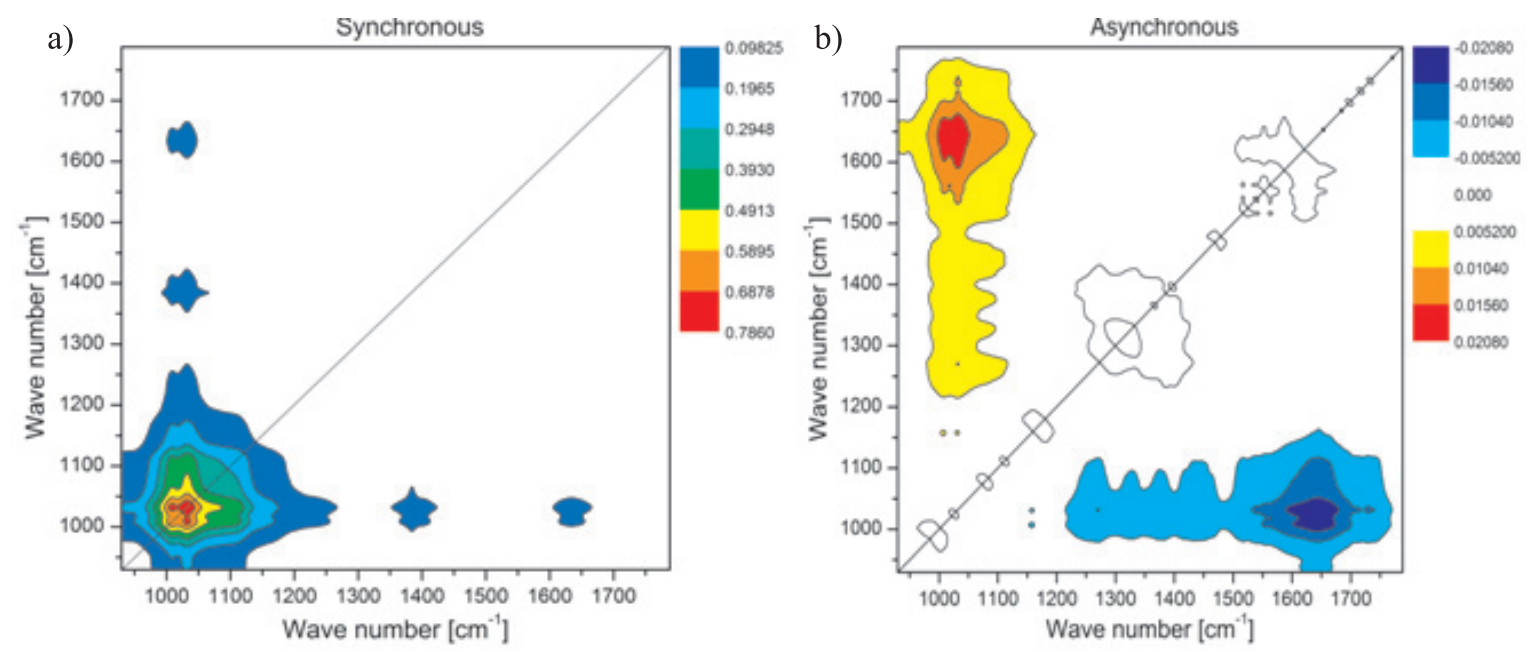

Fig. 5. Synchronous and asynchronous 2D-FTIR correlation spectra of Coleus blumei roots under $0 \mathrm{mM}$ and $1.0 \mathrm{mM}$ lead with $0.5 \mathrm{mM}$ Se treatment.

$1,033 \mathrm{~cm}^{-1}>1,270 \mathrm{~cm}^{-1}>1,333 \mathrm{~cm}^{-1}>1,645 \mathrm{~cm}^{-1}$. This sequence means that the moment of the $\mathrm{C}-\mathrm{O}$ groups $\left(1,033 \mathrm{~cm}^{-1}\right)$ in polysaccharides changes first, followed by the $\mathrm{C}$-O groups $\left(1,270 \mathrm{~cm}^{-1}\right), \mathrm{CH}_{2}$ stretching vibration in lipids/proteins $\left(1,333 \mathrm{~cm}^{-1}\right)$, and the $\mathrm{C}=\mathrm{C}$ stretching of the aromatic skeleton $\left(1,645 \mathrm{~cm}^{-1}\right)$ under $\mathrm{Pb}$ stress with $0.1 \mathrm{mM}$ Se.

In the synchronous $2 \mathrm{D}$ correlation spectrum of the Pb1.0Se0.5 treatment (Fig. 5a), one auto-peak at $\Phi(1,000-$ $1,150,1,000-1,150)>0$, one positive cross-peak at $\Phi(1,384$, $1,645)>0$, and 2 negative cross-peaks at $\Phi(1,000-1,150$, $1,384)<0$ and $\Phi(1,000-1,150,1,645)<0$ were observed. This implies that the band at $1,000-1,150 \mathrm{~cm}^{-1}$ varies in the opposite direction to the bands at $1,384 \mathrm{~cm}^{-1}$ and $1,645 \mathrm{~cm}^{-1}$. This means that the $\mathrm{C}-\mathrm{O}$ stretching vibrations $\left(1,000-1,150 \mathrm{~cm}^{-1}\right)$ vary in the opposite direction to the $\mathrm{CH}_{3}$ stretching $\left(1,384 \mathrm{~cm}^{-1}\right)$ and aromatic $\mathrm{C}=\mathrm{C}$ stretching $\left(1,645 \mathrm{~cm}^{-1}\right)$ under the $\mathrm{Pb} 1.0 \mathrm{Se} 0.5$ treatment, compared with the $\mathrm{Pb} 1.0 \mathrm{Se} 0$ treatment. Three bands at $1,125 \mathrm{~cm}^{-1}, 1,270 \mathrm{~cm}^{-1}$, and $1,645 \mathrm{~cm}^{-1}$ were identified in the asynchronous 2D correlation spectrum of the Pb1.0Se0.5 treatment (Fig. 5b). The sequence of the spectral intensity changes was obtained as follows: $1,125 \mathrm{~cm}^{-1}>1,270 \mathrm{~cm}^{-1}>1,645 \mathrm{~cm}^{-1}$. This sequence means that the moment of the $\mathrm{C}-\mathrm{O}$ groups in polysaccharides changes first, followed by the $\mathrm{C}=\mathrm{C}$ stretching of the aromatic skeleton under $\mathrm{Pb}$ stress with $0.5 \mathrm{mM}$ Se.

In the synchronous 2D correlation spectrum of the Pb1.0Se1.0 treatment (Fig. 6a), one auto-peak at $\Phi(1,000-1,150,1,000-1,150)>0$, one positive cross-peak at $\Phi(1,384,1,645)>0$, and two negative cross-peaks at $\Phi(1,000-1,150,1,384)<0$ and $\Phi(1,000-1,150,1,645)<0$ were observed. This implies that the band at $1,000-1,150 \mathrm{~cm}^{-1}$ varies in the opposite direction to the bands at $1,384 \mathrm{~cm}^{-1}$ and $1,645 \mathrm{~cm}^{-1}$,
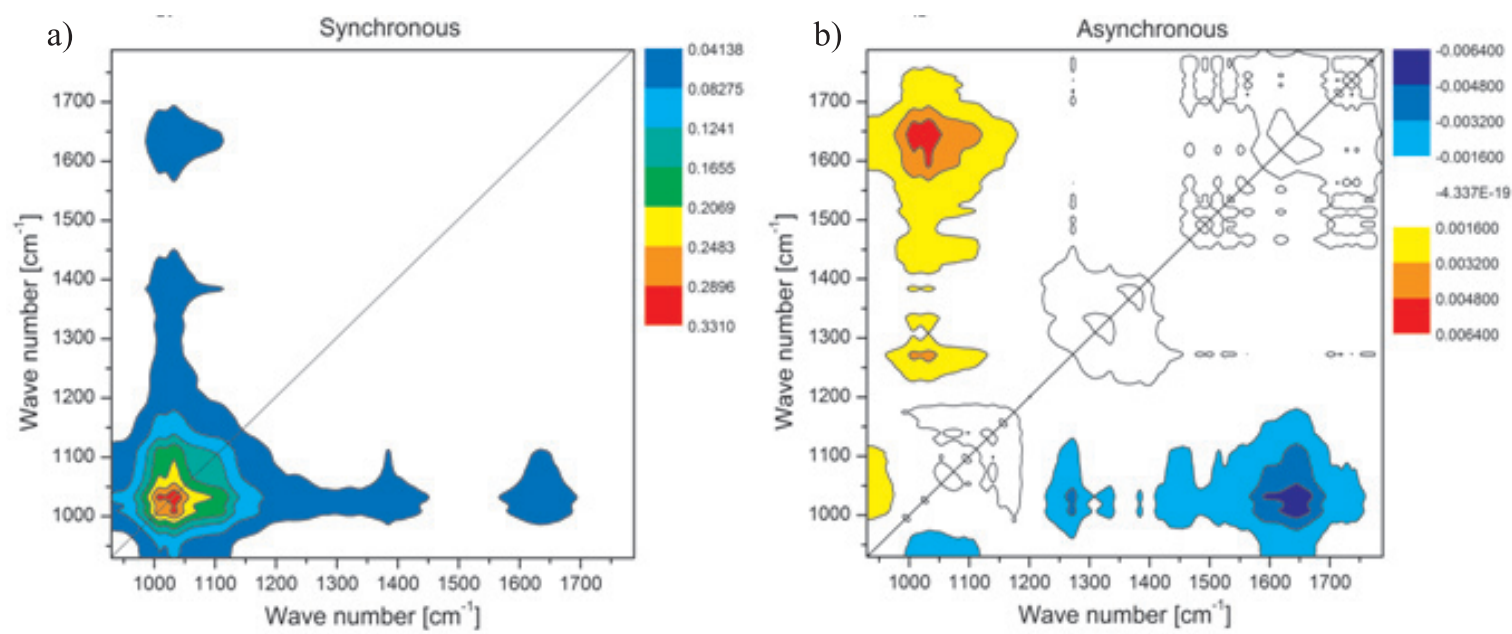

Fig. 6. Synchronous and asynchronous 2D-FTIR correlation spectra of Coleus blumei roots under $0 \mathrm{mM}$ and $1.0 \mathrm{mM}$ lead with $1.0 \mathrm{mM}$ Se treatment. 

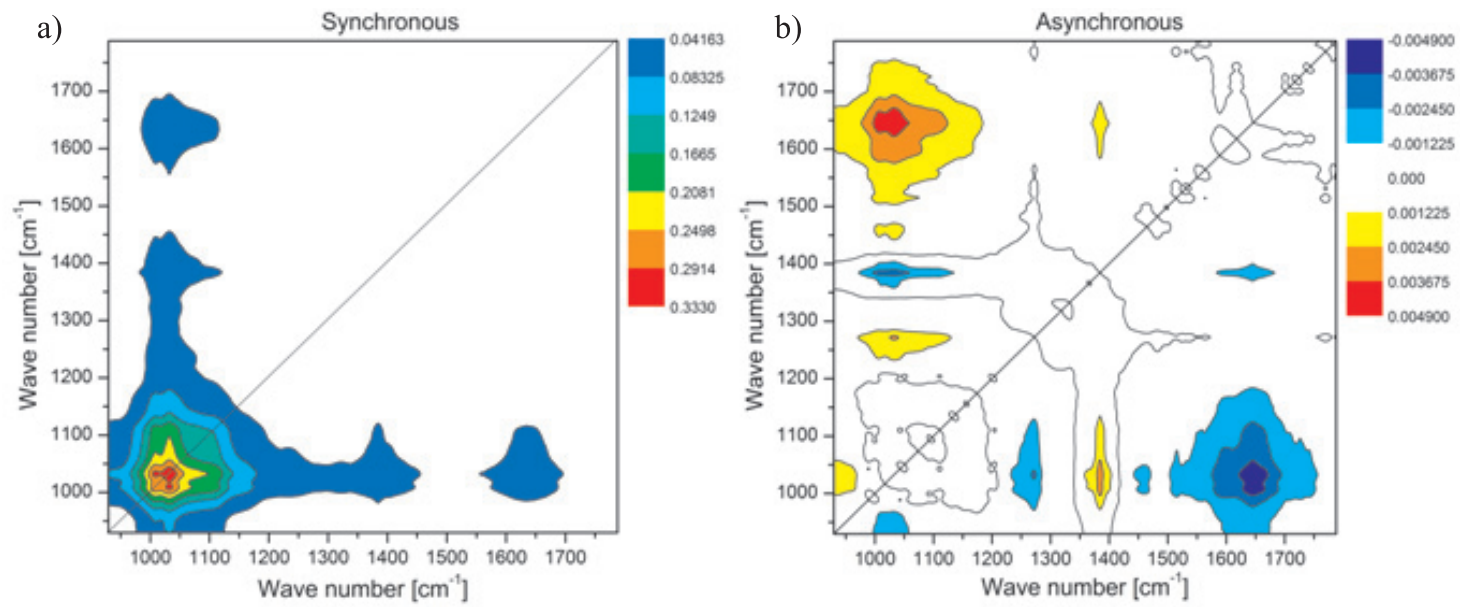

Fig. 7. Synchronous and asynchronous 2D-FTIR correlation spectra of Coleus blumei roots under $0 \mathrm{mM}$ and $1.0 \mathrm{mM}$ lead with $2.5 \mathrm{mM}$ Se treatment.

which means that the $\mathrm{C}-\mathrm{O}$ stretching vibrations $(1,000$ $1,150 \mathrm{~cm}^{-1}$ ) vary in the opposite direction to the $\mathrm{CH}_{3}$ stretching $\left(1,384 \mathrm{~cm}^{-1}\right)$ and aromatic $\mathrm{C}=\mathrm{C}$ stretching $\left(1,645 \mathrm{~cm}^{-1}\right)$ under the Pb1.0Se1.0 treatment compared with the Pb1.0Se0 treatment. Four bands at $1,033 \mathrm{~cm}^{-1}$, $1,270 \mathrm{~cm}^{-1}, 1,384 \mathrm{~cm}^{-1}$, and $1,645 \mathrm{~cm}^{-1}$ were identified in the asynchronous 2D correlation spectrum of the Pb1.0Se1.0 treatment (Fig. 6b). The sequence of the spectral intensity changes was obtained as follows: $1,033 \mathrm{~cm}^{-1}>1,384 \mathrm{~cm}^{-1}>1,270 \mathrm{~cm}^{-1}>1,645 \mathrm{~cm}^{-1}$. This sequence means that the moment of the $\mathrm{C}-\mathrm{O}$ groups in polysaccharides changes first, followed by the $\mathrm{CH}_{3}$ stretching vibration in the lipids/proteins, the $\mathrm{C}-\mathrm{O}$ stretching of the polysaccharides, and the $\mathrm{C}=\mathrm{C}$ stretching of the aromatic skeleton under $\mathrm{Pb}$ stress with $1.0 \mathrm{mM} \mathrm{Se}$.

In the synchronous 2D correlation spectrum of the Pb1.0Se2.5 treatment (Fig. 7a), one auto-peak at $\Phi(1,000-1,150,1,000-1,150)>0$, one positive crosspeak at $\Phi(1,384,1,645)>0$, and 2 negative cross-peaks at $\Phi(1,000-1,150,1,384)<0$ and $\Phi(1,000-1,150,1,645)$ $<0$ were observed. This implies that the band at $1,000-$ $1,150 \mathrm{~cm}^{-1}$ varies in the opposite direction to the bands at $1,384 \mathrm{~cm}^{-1}$ and $1,645 \mathrm{~cm}^{-1}$, which means that the $\mathrm{C}-\mathrm{O}$ stretching vibrations $\left(1,000-1,150 \mathrm{~cm}^{-1}\right)$ vary in the opposite direction to the $\mathrm{CH}_{3}$ stretching $\left(1,384 \mathrm{~cm}^{-1}\right)$ and the aromatic $\mathrm{C}=\mathrm{C}$ stretching $\left(1,645 \mathrm{~cm}^{-1}\right)$ under the $\mathrm{Pb} 1.0 \mathrm{Se} 2.5$ treatment compared with the $\mathrm{Pb} 1.0 \mathrm{Se} 0$ treatment. Five bands at $1,033 \mathrm{~cm}^{-1}, 1,270 \mathrm{~cm}^{-1}, 1,384$ $\mathrm{cm}^{-1}, 1,416 \mathrm{~cm}^{-1}$, and $1,645 \mathrm{~cm}^{-1}$ were identified in the asynchronous $2 \mathrm{D}$ correlation spectrum of the $\mathrm{Pb} 1.0 \mathrm{Se} 2.5$ treatment (Fig. 7b). The sequence of the spectral intensity changes was obtained as follows: $1,033 \mathrm{~cm}^{-1}>1,416 \mathrm{~cm}^{-1}$ $>1,270 \mathrm{~cm}^{-1}>1,384 \mathrm{~cm}^{-1}>1,645 \mathrm{~cm}^{-1}$. This sequence means that the moment of the $\mathrm{C}-\mathrm{O}\left(1,033 \mathrm{~cm}^{-1}\right)$ groups in the polysaccharides change first, followed by the $\mathrm{CH}_{2}$ groups $\left(1,416 \mathrm{~cm}^{-1}\right)$ and the $\mathrm{C}-\mathrm{O}$ stretching $\left(1,270 \mathrm{~cm}^{-1}\right)$ of the polysaccharides, the $\mathrm{CH}_{3}$ stretching vibration in the lipids/proteins $\left(1,384 \mathrm{~cm}^{-1}\right)$, and the $\mathrm{C}=\mathrm{C}$ stretching
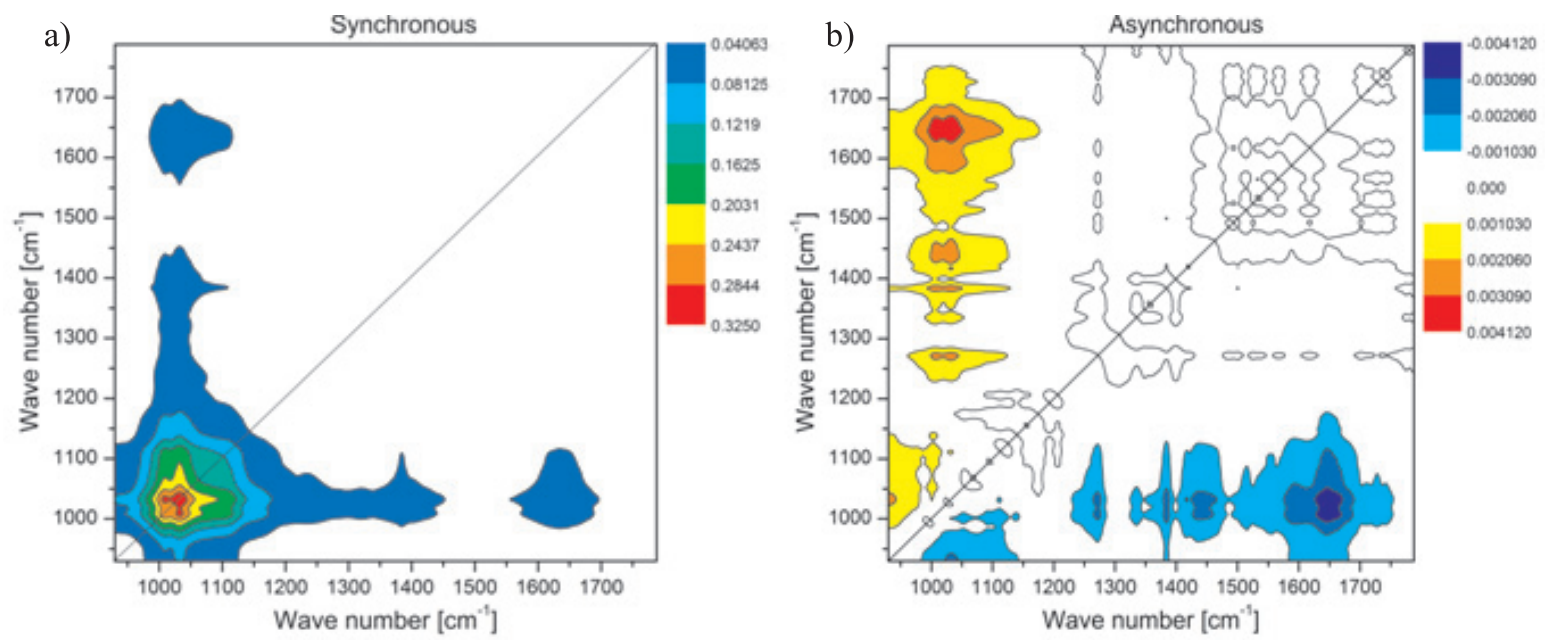

Fig. 8. Synchronous and asynchronous 2D-FTIR correlation spectra of Coleus blumei roots under $0 \mathrm{mM}$ and $1.0 \mathrm{mM}$ lead with $5.0 \mathrm{mM}$ Se treatment. 
of the aromatic skeleton $\left(1,645 \mathrm{~cm}^{-1}\right)$ under $\mathrm{Pb}$ stress with $2.5 \mathrm{mM} \mathrm{Se}$.

In the synchronous 2D correlation spectrum of the Pb1.0Se5.0 treatment (Fig. 8a), one auto-peak at $\Phi(1,000$ $1,150,1,000-1,150)>0$, one positive cross-peak at $\Phi(1,384$, $1,645)>0$, and 2 negative cross-peaks at $\Phi(1,000-1,150$, $1,384)<0$ and $\Phi(1,000-1,150,1,645)<0$ were observed. This implies that the band at $1,000-1,150 \mathrm{~cm}^{-1}$ varies in the opposite direction to the bands at $1,384 \mathrm{~cm}^{-1}$ and $1,645 \mathrm{~cm}^{-1}$. This means that the $\mathrm{C}-\mathrm{O}$ stretching vibrations $\left(1,000-1,150 \mathrm{~cm}^{-1}\right)$ vary in the opposite direction to the $\mathrm{CH}_{3}$ stretching $\left(1,384 \mathrm{~cm}^{-1}\right)$ and the aromatic $\mathrm{C}=\mathrm{C}$ stretching $\left(1,645 \mathrm{~cm}^{-1}\right)$ under the $\mathrm{Pb} 1.0 \mathrm{Se} 5.0$ treatment, compared to the $\mathrm{Pb} 1.0 \mathrm{Se} 0$ treatment. Five bands at $1,033 \mathrm{~cm}^{-1}, 1,270 \mathrm{~cm}^{-1}, 1,384 \mathrm{~cm}^{-1}, 1,416 \mathrm{~cm}^{-1}$, and $1,645 \mathrm{~cm}^{-1}$ were identified in the asynchronous 2D correlation spectrum of the Pb1.0Se5.0 treatment (Fig. 8b). The sequence of the spectral intensity changes was obtained as follows: $1,033 \mathrm{~cm}^{-1}$, $1,270 \mathrm{~cm}^{-1}>1,416 \mathrm{~cm}^{-1}>1,384 \mathrm{~cm}^{-1}>1,645 \mathrm{~cm}^{-1}$. This sequence means that the moment of the $\mathrm{C}-\mathrm{O}$ groups in the polysaccharides changes first, followed by the $\mathrm{CH}_{2}$ groups in the polysaccharides, the $\mathrm{CH}_{3}$ stretching vibration in the lipids/proteins, and the $\mathrm{C}=\mathrm{C}$ stretching of the aromatic skeleton under $\mathrm{Pb}$ stress with $5.0 \mathrm{mM}$ Se.

Based on the 2D-FTIR correlation spectra data, we found that most sensitive to $\mathrm{Pb}$ stress were the $\mathrm{C}-\mathrm{O}$ groups from the polysaccharides, followed by the $\mathrm{CH}_{3}$ group in the lipids/proteins, and the $\mathrm{C}=\mathrm{C}$ group of the aromatic skeleton. This indicates that the carboxyl $(\mathrm{C}=\mathrm{O})$ and aliphatic chains are mainly responsible for lead adsorption in $C$. blumei roots. Other studies have also reported that carboxyl $(\mathrm{C}=\mathrm{O})$ and phenol $(\mathrm{OH})$ groups make important contributions to $\mathrm{Pb}^{2+}$ sorption [47, 48]. However, with the addition of different concentrations of $\mathrm{Se}$ during $\mathrm{Pb}$ stress, these functional groups were responsible for $\mathrm{Pb}$ adsorption, as changes in the peaks were observed around the wavelengths of these groups. The Se concentration-dependent changes appeared in the infrared regions characteristic of the $\mathrm{C}=\mathrm{O}, \mathrm{CH}_{2}, \mathrm{CH}_{3}$, and $\mathrm{C}=\mathrm{C}$ stretching frequencies of the polysaccharides and the lipids/proteins. These results were in accordance with semi-quantitative data from the above 1D-FTIR spectra.

\section{Conclusions}

The peak shapes remained basically unchanged in C. blumei roots exposed to $\mathrm{Pb}$ stress with different concentrations of Se treatments, and the wave number of the absorption peaks remained stationary, which indicates that the chemical composition in the roots had not changed. However, there is a significant difference in the absorption peak strength, which is influenced by the chemical composition. Semi-quantitative data indicate that there were obvious differences among the characteristics of the organic functional groups.
The FTIR spectrum confirms the presence of various functional groups from the responses to abiotic stresses in the plant, which may influence the reduction process and stabilization of heavy metals.

There were obvious differences among the 2D-FTIR correlation spectra of $C$. blumei roots in the region of 929$1,800 \mathrm{~cm}^{-1}$ under $\mathrm{Pb}$ stress with different concentrations of Se treatments. Significant differences between the 2D-FTIR correlation spectra of $C$. blumei roots are likely to be related to differences in chemical composition and its structure. The high resolution 2D-FTIR technology based on similar samples as the one-dimensional infrared spectrum can provide the microscopic information from the dynamic changes of chemical composition structure resulting from Se concentration changes. The results demonstrate that 2D-FTIR correlation spectroscopy may be a convenient and effective method in the study of plant molecular interactions under environmental stress.

\section{Acknowledgements}

This work was financially supported by the National Natural Science Foundation of China (grant Nos. 21407069, 21367013), the Natural Science Foundation of Jiangxi Province, China (Nos. 20142BAB203024, 20151BAB203034), and the Youth Elite Support Plan in Jiangxi University of Finance and Economics (No. K00292025). We also would like to thank the native English-speaking scientists of Elixigen Company (Huntington Beach, California) for editing our manuscript. We are most grateful and would like to thank the reviewers for their valuable suggestions that led to substantial improvement of the article.

\section{References}

1. FARD K.G., GHASEMNEZHAD M., ZAKIZADEH H., KAFI M., REJALI F. Evaluation of six cold-season turfgrasses responses to lead phytotoxicity for screening tolerant species. Caspian J. Environ. Sci. 14 (3), 215, 2016.

2. THUPPIL V., TANNIR S. Treating lead toxicity: Possibilities beyond synthetic chelation. Journal of Krishna Institute of Medical Sciences University (JKIMSU), 2(1), 4, 2013.

3. SHARMA P., DUBEY R.S. Lead toxicity in plants, Braz. J. Plant Physiol. 17 (1), 35, 2005.

4. BAGHAIE A., KHOSHGOFTARMANESH A., AFYUNI M. Phytoavailability of lead $(\mathrm{Pb})$ for corn and sunflower as affected by $\mathrm{Pb}$-enriched sewage sludge and cow manure. J. Residuals Sci. Tech. 13(4), 251, 2016.

5. JORDAO C.P., NASCENTES C.C., CECON P.R., FONTES R.L.F., PEREIRA J.L. Heavy metal availability in soil amended with composted urban solid wastes. Environ. Monit. Assess. 112 (1-3), 309, 2016.

6. LIU D., JJIANG W., LIU C., XIN C., HOU W. Uptake and accumulation of lead by roots, hypocotyls and shoots of Indian mustard Brassica juncea L.. Bioresource Technol. 71 (3), 273, 2000. 
7. MROCZEK-ZDYRSKA M., WÓJCIK M. The influence of selenium on root growth and oxidative stress induced by lead in Vicia faba L. minor plants. Biol. Trace Elem. Res. 147 (1-3), 320, 2012.

8. MROCZEK-ZDYRSKA M., STRUBIŃSKA J., HANAKA A. Selenium improves physiological parameters and alleviates oxidative stress in shoots of lead-exposed Vicia faba L. minor plants grown under phosphorus-deficient conditions. J. Plant Growth Regul. 36 (1), 186, 2016.

9. ELGAML S.A., KHALIL R., HASHISH E.A., EL-MUR A. Protective effects of selenium and alpha-tocopherol against lead induced hepatic and renal toxicity in Oreochromis niloticus. J. Aquac. Res. Development. 6 (1), 1, 2015.

10. HU Y., NORTON G.J., DUAN G., HUANG Y.C., LIU Y.X. Effect of selenium fertilization on the accumulation of cadmium and lead in rice plants. Plant and Soil. 384 (1), 131, 2014.

11. HE P.P., LV X.Z., WANG G.Y. Effects of Se and Zn supplementation on the antagonism against $\mathrm{Pb}$ and $\mathrm{Cd}$ in vegetables. Environ. Int. 30 (2), 167, 2004.

12. POPESCU M.C., ZANOAGA M., MAMUNYA Y., MYSHAK V., VASILE C. Two dimensional infrared correlation spectroscopy studies of wood-plastic composites with a copolyamide as matrix. J. Optoelectron Adv. M. 9 (4), 923, 2007.

13. LIU X.Y., ZHOU T., WANG X.C., ZHANG J.H. Investigation of selective molecular interactions using two-dimensional Fourier transform IR spectroscopy. Anal. Bioanal. Chem. 397 (1), 339, 2010.

14. PARROTTA L., GURRRIERO G., SERGEANT K., CAI G., HAUSMAN J.F. Target or barrier? The cell wall of early- and later-diverging plants vs cadmium toxicity: differences in the response mechanisms. Front Plant Sci. 6 (133), 1, 2015.

15. UCHIMIYA M., BANNON D.I., WARTELLE L.H. Retention of heavy metals by carboxyl functional groups of biochars in small arms range soil. J. Agric. Food Chem. 60 (7), 1798, 2012.

16. KHABIBI J., SYAFII W., SARI R.K. Reducing hazardous heavy metal ions using mangium bark waste. Environ. Sci. Pollut. Res. 23 (6), 1, 2016.

17. YUAN J.H., HU, M.H., ZHOU Z.H. Selenium alleviates coleus from oxidative damage under $\mathrm{Pb}$ stress by resource allocation and antioxidant defense system. Res. J. Appl. Sci. Eng. Technol. 6 (9), 1606, 2013.

18. HOAGLAND D.R., ARMON D.I. The water culture method for growing plants without soil, Cal. Agri. Expt. Sta. Cir. 347 (5406), 357, 1950.

19. ZHAO L.Z., MAO D., LIN Z.Y. Effects of different nutrient solution on pigment content and photosynthesis of Coleus blumei. Chinese Guangdong Agricultural Sciences, (6), 30, 2007 [In Chinese].

20. WANG Y.L., LI Y.N., SUN W.W., SONG Q. Research on chemical substance in pueraria lobata by FTIR and HPLC. Modernization of Traditional Chinese Medicine and Materia Medica-World Science and Technology. 16 (2), 379, 2014.

21. KUBBA R.M., SAMAWI K.A. Studying of frequencies, normal modes of vibration and electronic charge densities of radialene molecule. Iraqi J. Sci. 54 (4), 753, 2013.

22. RENGANAYAKIV., SYAMALAD., SATHYAMOORTHY R. Growth, Structural and spectral studies on pure and doped ammonium dihydrogen phosphate (ADP) single crystals. Arch. Appl. Sci. Res. 4 (3), 1453, 2012.

23. BARTOŠOVÁ A.; SOLDÁN M., SIROTIAK M., BLINOVÁ L., MICHALIKOVÁ A. Application of
FTIR-ATR spectroscopy for determination of glucose in hydrolysates of selected starches. Res. Papers Faculty Mater. Sci. Technol. Slovak Univ. Technol. 21 (Special Issue), 116, 2013.

24. HANDS J.R., CLEMENS G., STABLES R., ASHTON K., BRODBET A., DAVIS C., DAWSON T.P., JENKINSON M.D., LEA R.W., WALKER C., BAKER M.J. Brain tumour differentiat ion: rapid stratified serum diagnostics via attenuated total reflection Fourier-transform infrared spectroscopy. J. Neurooncol. 127 (3), 463, 2016.

25. CAUNII A., PRIBAC G., GROZEA I., GAITIN D., SAMFIRA I. Design of optimal solvent for extraction of bio-active ingredients from six varieties of Medicago sativa. Chem. Cent. J. 6 (1), 123, 2012.

26. FEO J.C., CASTRO M.A., ROBLES L.C., ALLER A.J. Fourier-transform infrared spectroscopic study of the interactions of selenium species with living bacterial cells. Anal. Bioanal. Chem. 378 (6), 1601, 2004

27. YU P.Q. Board-invited review: sensitivity and responses of functional groups to feed processing methods on a molecular basis. J. Anim. Sci. Biotechno. 4 (1), 42, 2012.

28. MOHANED G.F., SHAHEEN M.S., KHALIL S.K.H., HUSSEIN A.M.S., KAMIL M.M. Application of FTIR spectroscopy for rapid and simultaneous quality determination of some fruit products, Nature \& Science, 9 (11), 21, 2011.

29. RASULI R., MOKARIAN Z., KARIMI R., SHABANZADEH H., ABEDINI Y. Wettability modification of graphene oxide by removal of carboxyl functional groups using non-thermal effects of microwave. Thin Solid Films. 589 (5), 364, 2015.

30. WAN P., WU J.Y., TAN L.L., ZHANG B.C., YANG K. Research on super-hydrophobic surface of biodegradable magnesium alloys used for vascular stents. Mater. Sci. Eng. C. Mater. Biol. Appl. 33 (5), 2885, 2013.

31. ZHANG Z.S., TAO Y.J., YANG Z.G., MAI K.C. Preparation and characteristics of nano- $\mathrm{CaCO}_{3}$ supported b-nucleating agent of polypropylene. Eur. Polym. J. 44 (7), 1955,2008

32. DUYGU D.Y., UDOH A.U., OZER T.B., AKBULUT A., ERKAYA I.A., YILDIZ K., GULER D. Fourier transform infrared (FTIR) spectroscopy for identification of Chlorella vulgaris Beijerinck 1890 and Scenedesmus obliquus (Turpin) Kützing 1833. Afr. J. Biotechnol. 11 (16), 3817, 2012.

33. SZCZEPANIK B., SLOMLIEWICZ P., GARNUSZEK M., CZECH K., DARIUSZ-BANAŚ D., KUBALA-KUKUŚ A., STABRAWA I. The effect of chemical modification on the physico-chemical characteristics of halloysite: FTIR, XRF, and XRD studies. J. Mol. Struct. 1084, 16, 2015.

34. XIONG J., ZHU W.S., LI H.M., XU Y.H., JIANG W., XUN S.H., LIU H. Immobilized fenton-like ionic liquid: catalytic performance for oxidative desulfurization. AIChE J. 59 (12), 4696, 2013.

35. AROKE U.O., EL-NAFATY U.A. XRF, XRD and FTIR properties and characterization of HDTMA-Br surface modified organo-kaolinite clay. Int. J. Emerging Tech. Adv. Eng. 4 (4), 817, 2014.

36. SOUSA E.C., UCHÔ-THOMAZ A.M.A., CARIOCA J.O.B., MORAIS S.M., LIMA A., MARTINS C.G., ALEXANDRINO C.D., FERREIRAP P.A.T., RODRIGUES A.L.M., RODRIGUES S.P., SILVA J.N., RODRIGUES L.L. Chemical composition and bioactive compounds of grape pomace (Vitis vinifera L.), Benitaka variety, grown in the semiarid region of Northeast. Brazil. Food Sci. Technol. 34 (1), 135, 2014. 
37. SIMÕES T., FONSECA S.B., AUGUSTO A., GRANADA L., OZÓRION R.O.A., GONÇALVES J.F.M., PASCOAL L.A.F., SILVA J.H.V., LEMOS M.F.L. Changes in fatty acid profile and chemical composition of meagre (Argyrosomus regius) fed with different lipid and selenium levels. Eur. J. Lipid Sci. Tech. 119 (6), 100, 2017.

38. SHARMA B., SINGH S., SIDDIQI N.J. Biomedical implications of heavy metals induced imbalances in redox systems. BioMed Res. Int. 2014 (1), 1, 2014.

39. KHOSHKISH M., BOUHENDI H., VAFAYAN M. Effect of $\mathrm{CO}_{2}$ fixation reaction on the thermal and dynamic mechanical properties of tetrafunctional epoxy resin. J. Mater. Sci. 49 (19), 6813, 2014.

40. ZODROW E.L. Molecular self-assembly: hypothesized for "hair" of Macroneuropteris scheuchzeri (Pennsylvanianage seed-fern). Int. J. Coal Geol. 121, 14, 2014.

41. D'ANGELO J.A., ZODROW E.L. Chemometric study of structural groups in medullosalean foliage (Carboniferous, fossil Lagerstätte, Canada): Chemotaxonomic implications. Int. J. Coal Geol. 138 (6), 42, 2015.

42. GANZ H., KALKREUTH W. Application of infrared spectroscopy to the classification of kerogentypes and the evaluation of source rock and oil shale potentials. Fuel, $\mathbf{6 6}$ (5), 708, 1987.

43. ZODROW E.L., MASTALERZ M. Functional groups in a single pteridosperm species: variability and circumscription
(Pennsylvanian, Nova Scotia, Canada). Int. J. Coal Geol. 70 (4), 313, 2007.

44. NODA I. Generalized 2-dimensional correlation method applicable to infrared, raman, and other types of spectroscopy. Appl. Spectrosc. 47 (9), 1329, 1993.

45. NODA I. Determination of two-dimensional correlation spectra using the hilbert transforms, Appl. Spectrosc. 54 (7), 994, 2000.

46. MURAYAMA K., WU Y., CZARNIK-MATUSEWICZ B., OZAKI Y. Two-dimensional/attenuated total reflection infrared correlation spectroscopy studies on secondary structural changes in human serum albumin in aqueous solutions: $\mathrm{pH}$-dependent structural changes in the secondary structures and in the hydrogen bondings of side chains. J. Phys. Chem. B. 105 (20), 4763, 2001.

47. DING T., LU C.W., HE J., ZHAO B.Y., WANG J.H., HE E., ZHOU H.J., ZHANG Y. Adsorption characteristics of $\mathrm{Pb}^{2+}$ on natural black carbon extracted from different grain-size lake sediments. Environ. Sci. Pollut. Res. 23 (23), 23911, 2016.

48. NADEEM R., MANZOOR Q., IQBAL M., NISAR J. Biosorption of $\mathrm{Pb}(\mathrm{II})$ onto immobilized and native Mangifera indica waste biomass. J. Ind. Eng. Chem. 35, 185, 2016. 